\title{
The effects of oestrogen receptors $\alpha$ and $\beta$ on testicular cell number and steroidogenesis in mice
}

\author{
M L Gould, P R Hurst and H D Nicholson \\ Department of Anatomy and Structural Biology, School of Medical Sciences, University of Otago, PO Box 913, \\ Dunedin, New Zealand \\ Correspondence should be addressed to H D Nicholson; Email: helen.nicholson@stonebow.otago.ac.nz
}

\begin{abstract}
Oestrogen plays an important role in testicular function. This study used mice null for oestrogen receptor $\alpha$ (ER $\alpha)$ or $\beta$ (ER $\beta$ ) to investigate which receptor mediates the effects of oestrogen within the testis. Groups of ER $\alpha$ knockout mice ( $\alpha E R K O)$ and ER $\beta$ knockout mice $(\beta E R K O)$ and wild-type littermates $(n=5-8)$ were killed at 11 weeks post partum. One testis was fixed in Bouin's fluid for stereology and the other frozen for testosterone measurement. Trunk blood was collected for testosterone RIA. The optical disector combined with the fractionator methodology was used to estimate Leydig, Sertoli and germ cell numbers. At all times, the knockout animals were compared with their wild-type littermates. The physical disector quantified cells stained immunohistochemically for the apoptotic marker active caspase-3 and Hoechst staining was used to identify nuclear fragmentation. The mean Leydig cell volume was measured using the point sampled intercept method. The Leydig cell number per testis was significantly increased in $\beta E R K O$ mice but not in $\alpha E R K O$ mice. Plasma and testicular testosterone concentrations were increased in $\alpha E R K O$ mice but no changes were observed in $\beta E R K O$ mice. Hypertrophic Leydig cell changes were observed in $\alpha E R K O$ mice, and a decreased mean cell volume was seen in $\beta E R K O$ mice. No difference in Sertoli cell number per testis was observed in any of the groups. The spermatogonial cell number per testis was increased in $\beta E R K O$ mice. Immunohistochemistry identified increased numbers of active caspase-3-labelled germ cells per testis in $\alpha$ ERKO mice but not $\beta E R K O$ mice. Hoechst staining supported these findings. There was significant germ cell loss in $\alpha E R K O$ mice. This study suggests that ER $\beta$ may be involved in regulation of Leydig cell proliferation and testosterone production in the adult mouse testis.

Reproduction (2007) 134 271-279
\end{abstract}

\section{Introduction}

It is now evident that oestrogen plays an important role in male reproductive function (see reviews by Couse \& Korach 1999, O'Donnell et al. 2001). Oestrogen is produced within the testis by the aromatisation of testosterone (Nitta et al. 1993) and has been shown to affect the major cell types within the organ. Administration of exogenous oestrogen during development has been shown to reduce Sertoli cell numbers in the adult (Atanassova et al. 1999) but the effect of endogenous oestrogen in this process is less clear. Oestrogen disrupts development of fetal Leydig cells (Delbes et al. 2005) and can also act directly on the Leydig cell to inhibit testosterone production (Zhai et al. 1996). Oestrogen has also been shown to inhibit gonocyte development in the fetal testis (Delbes et al. 2004) and in the adult to enhance spermatogenesis by inhibiting apoptosis of human post-meiotic germ cells (Pentikainen et al. 2000).

The effects of oestrogen are mediated by two distinct receptors: oestrogen receptor $\alpha(E R \alpha)$ and $\beta(E R \beta)$, both of which are found within the testis. ER $\beta$ appears to be the more abundant being localised in the mouse to the Leydig and Sertoli cells as well as spermatogonia and elongated spermatids (Rosenfeld et al. 1998, Jefferson et al. 2000). ER $\alpha$ has been identified in adult Leydig cells (Zhou et al. 2002) and are thus the only cells in the mouse testis reported to express both ERs.

While the localisation of the ERs is becoming clearer, the biological functions mediated by each receptor are less well established. Studies of the ER $\alpha$ knockout mouse ( $\alpha$ ERKO) have demonstrated that although the testes of these animals begin to develop normally, by 20 days post partum there is dilation of the lumen of the seminiferous tubules and rete testis. A reduced fluid reabsorption in the efferent ducts (Hess 2000) results in testicular disruption and loss of germ cells in the tubules culminating in subsequent infertility (Lubahn et al. 1993). How these changes influence Sertoli cell numbers remains unknown. Male ER $\beta$ knockout mice $(\beta E R K O)$, on the other hand, are reported to have 
normal fertility, even though the $\beta$ ERKO females have reduced fertility when compared with their wild-types (Krege et al. 1998).

As well as abnormalities in the seminiferous epithelium the inactivation of $E R \alpha$ also affects testosterone production. $\alpha$ ERKO mice exhibit increased folliclestimulating hormone (FSH) levels and also have raised circulating concentrations of luteinizing hormone $(\mathrm{LH}$; Lindzey et al. 1998) and testosterone (Akingbemi et al. 2003). Leydig cells in the $\alpha$ ERKO mice are hypertrophic and have been shown to produce more testosterone than cells from wild-type mice (Akingbemi et al. 2003).

The effects of ER $\beta$ on the seminiferous epithelium and Leydig cells are less clear. Delbes et al. (2004) have demonstrated that $E R \beta$ may affect proliferation of gonocytes during development but found no effect on the number or testosterone production of fetal Leydig cells at 2 days post partum.

The aim of this study was to investigate the effects of loss of the ER $\beta$ receptor on cellular makeup of the testis in the adult mouse and to determine whether lack of ER $\alpha$ affects Sertoli cell number.

\section{Materials and Methods}

\begin{abstract}
Animals
Adult $\alpha$ ERKO and $\beta E R K O$ mice were kind donations from Prof. Allan Herbison (Department of Physiology, University of Otago). ERKO mice and wild-type littermates were generated by mating $\mathrm{C} 57 \mathrm{BL} / 6$ J heterozygous mice expressing the disrupted $\mathrm{ER} \alpha$ (Lubahn et al. 1993) or ERß gene (Krege et al. 1998). Genotyping of the offspring was performed on tail-tip DNA using PCR amplification (Couse et al. 2003).

Mice were housed under $12 \mathrm{~h}$ light: $12 \mathrm{~h}$ darkness cycles and given food and water ad libitum. Experiments were performed with approval from the University of Otago Animal Ethics Committee in accordance with the New Zealand Animal Welfare Act of 1999.
\end{abstract}

\section{Tissue collection}

Male $\alpha$ ERKO mice $(n=8)$ and their wild-type littermates $(n=8)$, and male $\beta$ ERKO mice $(n=8)$ and their wild-type littermates $(n=5)$ were killed at 11 weeks post partum by $\mathrm{CO}_{2}$ inhalation. The testes were removed and one fixed overnight in Bouin's fluid and then stored in 70\% alcohol until processing for histological analysis and the other flash-frozen in liquid nitrogen and stored at $-80{ }^{\circ} \mathrm{C}$. Trunk blood was collected and plasma and testicular testosterone concentrations measured by RIA (Yeung et al. 1988).

\section{Cell number estimation using the optical disector}

A fractionated sample combined with the optical disector has been shown to be a precise method to estimate testis cell number (Wreford 1995). Each testis was fractionated according to the smooth fractionation method (Gundersen 2002) into 12 pieces from which four blocks were selected randomly. Each selected block was sectioned exhaustively into $30 \mu \mathrm{m}$ sections and one section from each selected randomly and stained using the periodic acid Schiff (PAS) technique (Clermont \& Perey 1957). Microscope images were captured on Spot analysis software (Diagnostic Instruments Inc., Sterling Heights, MI, USA) using a $100 \times$ oil free objective (NA 0.95) on an Olympus BX-51 microscope with a Spot RT colour camera attachment. A $100 \mathrm{~mm} \times 100 \mathrm{~mm}$ square reference frame (Howard \& Reed 1998) was placed on the computer screen over the captured microscope images. The disector was imaged through the $z$-axis initially incorporating a $2 \mu \mathrm{m}$ guard zone that randomly and systematically traversed the entire section. The optical disector method was used to count the nucleus of each cell (Gundersen 1986, Gundersen et al. 1988).

The testicular cells were identified by the following criteria (see Fig. 1): Leydig cells were located within the interstitial tissue and identified by their round to ovoid cell margins with a single identifiable nucleus. Sertoli cells were identified by their irregular tripartite nucleolus (Russell et al. 1990) and their location within the lower third of the seminiferous tubule. Spermatogonia were located adjacent to the basement membrane and did not exhibit PAS staining but rather a particulate appearance of their nuclei (Leblond \& Clermont 1952).

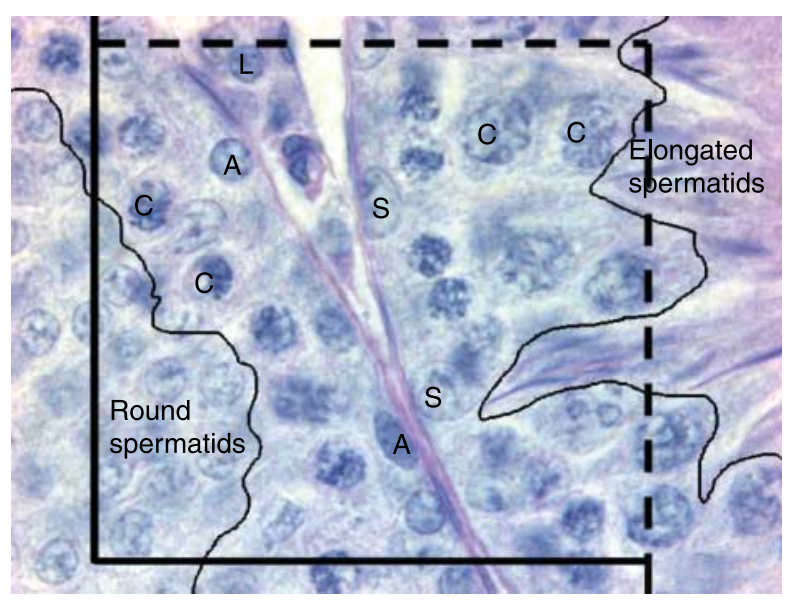

Figure 1 Histology of the testis. The testis cells are annotated inside the disector frame. Cells that appeared completely within the frame or intersect the dashed inclusion lines were counted. Cells that intersect the solid exclusion lines were not counted. L, Leydig; S, Sertoli; A, spermatogonia; C, spermatocytes. The round and the elongated spermatids are identified on the left and right respectively. 
Spermatocytes were larger, contained clumped chromatin and meiotic chromatin. Spermatids had characteristic PAS staining of the acrosome in both round and elongating cells (Russell et al. 1990). On an average, $68 \pm 6$ Leydig cells; $82 \pm 6$ Sertoli cells; $48 \pm 3$ spermatogonia; $549 \pm 165$ spermatocytes; $1538 \pm 556$ spermatids; $150 \pm 11$ caspase-positive cells and 118 \pm 28 Hoechst-positive cells were counted in the disectors for each animal.

\section{Point counting}

Sections selected for stereology were also used to determine the tissue constituents in the $\alpha E R K O$ and $\beta E R K O$ mice and their wild-type littermates. Six images from each animal were captured at $10 \times$ magnification, and using a randomly placed $20 \mathrm{~mm}$ grid the percentage $(\mathrm{V} v)$ of seminiferous tubules and interstitial tissue was determined.

\section{Measurement of apoptotic germ cells}

To investigate whether there was an increased rate of regulated cell death in the $\beta$ ERKO mice during and after meiosis and to determine if the cellular loss seen in the $\alpha$ ERKO was due to active caspase- 3 activity, the number of cells exhibiting immunostaining for activated caspase3 was compared between the knockout and wild-type mice using a method developed by Fenwick \& Hurst (2002). Briefly, sections $(5 \mu \mathrm{m})$ were deparaffinised in xylene and rehydrated through graded alcohols into distilled water. Antigens were unmasked by boiling for $20 \mathrm{~min}$ in $0.1 \mathrm{~mol}$ Tris- $\mathrm{HCl}$ buffer $(\mathrm{pH} 10)$ with $5 \%(\mathrm{w} / \mathrm{v})$ urea (Shi et al. 1996). Peroxidase activity was quenched with $0.3 \% \quad \mathrm{H}_{2} \mathrm{O}_{2}(\mathrm{v} / \mathrm{v})$ in methanol. Sections were blocked with a 1:200 dilution of donkey serum for $10 \mathrm{~min}$ and then incubated in rabbit anti-active caspase3 polyclonal antibody overnight at $4{ }^{\circ} \mathrm{C}$ (Cell Signaling, Boston, MA, USA). Negative control sections were incubated with an equivalent concentration of rabbit immunoglobulin G (IgG). The sections were incubated in biotinylated anti-rabbit IgG (Amersham Pharmacia Biotech) at a dilution of 1:200 for $30 \mathrm{~min}$ and then streptavidin-biotinylated horseradish peroxidase complex (Amersham Pharmacia Biotech) at a dilution of 1:200 for 30 min. Immunoreactivity was visualized with 3-amino-9-ethylcarbazole (Sigma-Aldrich Co.) and counterstained with Harris Haematoxylin.

Slides were viewed under an Olympus BX-51 microscope. Images were captured using the Spot imaging system. The physical disector (Sterio 1984) was used with pairs of serial sections mounted on the same slide and with systematic random sampling across the sections. At least 100 immunopositive cells were scored within the disector reference frames.
Hoechst staining was used as another approach to study and count the numbers of apoptotic cells. Morphological criteria identified apoptotic cells with nuclear fragmentation, blebbing and chromatin condensation. Apoptotic cells stained with Hoechst were intensely bright and irregularly stained. Normal cells were lightly regularly stained and residual bodies remained unstained. Cells were scored as apoptotic if they exhibited a bright fluorescent staining as well as defined morphological criteria. Tissue from randomly selected blocks were cut $(5 \mu \mathrm{m})$ and dewaxed. After equilibrating in PBS for 5 min, the Hoechst stain ( $\mathrm{H}-3570$, Molecular Probes, Eugene, Oregon, USA) was applied $(10 \mu \mathrm{g} / \mathrm{ml}$ in PBS) for $10 \mathrm{~min}$ in the dark. The slides were washed in PBS for $5 \mathrm{~min}$ and then coverslipped using Vectorshield mounting media ( $\mathrm{H}-1000$, Vector Laboratories, Burlingame, CA, USA). The physical disector method was used to count Hoechst stained cells in a manner identical to the method used for active caspase-3 immunostaining.


Figure 2 Comparison of (a) body weight and (b) testicular weight between $\alpha$ and $\beta$ oestrogen receptor knockout mice. Bars represent mean \pm S.E.M. $\alpha$ WT ( $\alpha$ wild-type littermates) $n=8, \alpha$ ERKO body weight $n=8, \alpha$ ERKO testis weight $n=7, \beta \mathrm{WT}$ ( $\beta$ wild-type littermates) $n=5$, $\beta$ ERKO $n=8$. ${ }^{* *} P<0.005,{ }^{* * *} P<0.001$ when compared with wildtype mice. 


\section{Mean Leydig cell volume}

It has previously been described that $\alpha$ ERKO mice have hypertrophic Leydig cells and increased circulating testosterone levels (Akingbemi et al. 2003). In this study, the optical disector determined that there were changes in Leydig cell numbers in $\beta E R K O$ mice. To determine if there were changes in the Leydig cell volume of the knockout mice when compared with their wild-type littermates, the point sampled intercept method was used (Gundersen et al. 1988).

Using the same images that were randomly captured for Hoechst staining, the Leydig cell outlines were clearly identified due to their distinct morphology. A sine weighted frame was placed on the image and the intercept test grid was placed so that one of the intercept lines passed through the bottom left corner as well as a randomly selected number.

Using Spot analysis software and following the intercept grid as a guide, a line was drawn across the chosen cells. One hundred cell intercepts were measured for each animal.

\section{Testosterone RIAs}

Testosterone was extracted from plasma with ether according to the method of Pierantoni et al. (1984) and from tissue using the method of Fink et al. (2005). Testosterone was measured in the extracted tissue and plasma samples (Yeung et al. 1988). The interassay variation was $6.3 \%$ and the intraassay variation was
$2.8 \%$ for the testicular testosterone and $7.6 \%$ for the plasma testosterone RIAs.

\section{Statistical analyses}

All statistical analyses were performed using GraphPad Prism 4.0 (GraphPad Software Inc., San Diego, CA, USA). Data are expressed as the mean \pm s.E.M.

When comparing the knockout animals with their wild-type littermates, the Student's unpaired t-test was used to determine significance. The significance level was set at $P<0.05$. When determining significance across all groups, the ANOVA was used with a post hoc Bonferroni correction test with the significance level set at $P<0.05$.

The coefficient of error equation was used to test variability of the observations to ensure adequate sampling (Gundersen \& Jensen 1987). This equation was used for the optical disector, the physical disector and point counting.

\section{Results}

No significant differences in body weight between the $\alpha$ ERKO ( $t$-test; $P=0.42$ ) or $\beta$ ERKO mice ( $t$-test; $P=0.77$ ) and their respective wild-type littermates were seen. There was, however, a significant difference in body weight between the two groups of wild-type littermates (Bonferroni, $P<0.001$; Fig. 2a). Testis weight was significantly reduced in the $\alpha E R K O$ mice when compared with the wild-type controls ( $t$-test; (a)

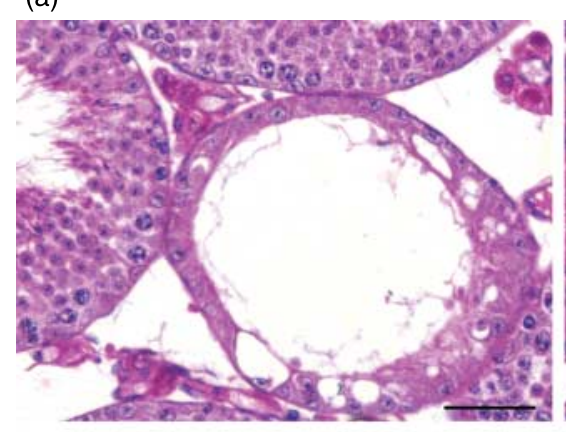

(c)

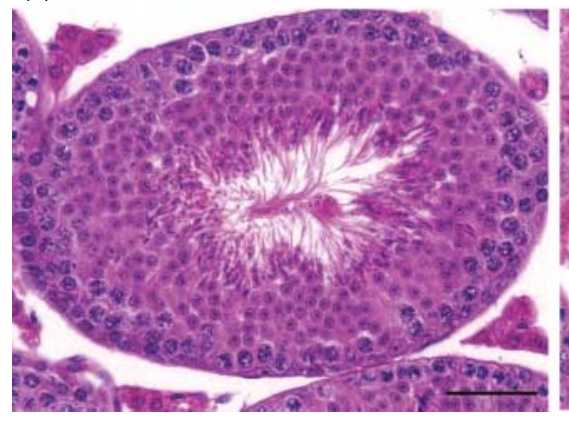

(b)

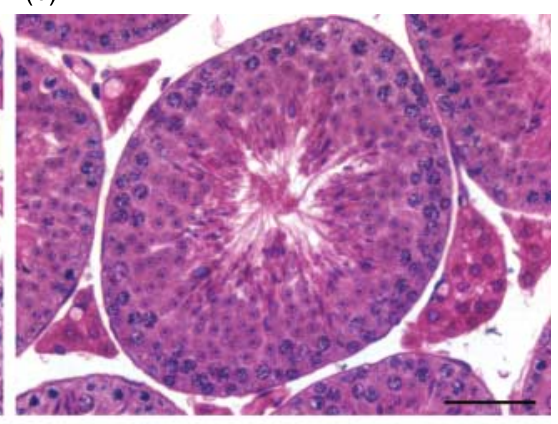

(d)

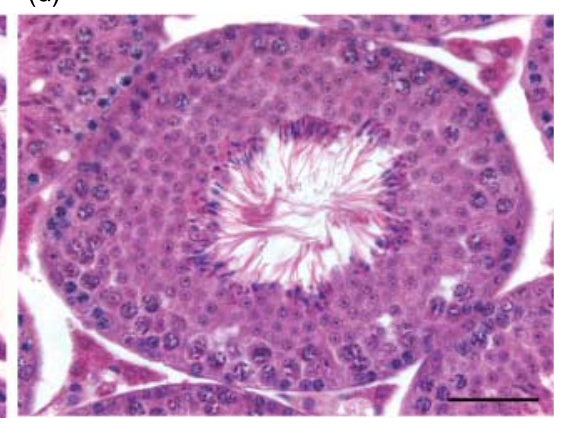

Figure 3 Haematoxylin- and eosin-stained sections of testis showing (a) seminiferous tubule disruption with severe cellular loss in the $\alpha$ ERKO mice. In atrophic tubules, Sertoli cells are seen lining the basement membrane. (b) $\beta E R K O$ testes showing normal tubules with increased Leydig cell numbers. (c) Testis sections from the $\alpha$ ERKO wild-type littermate's and (d) from the $\beta E R K O$ wild-type littermates showed normal morphology. Bars $=50 \mu \mathrm{m}$. 
$P=0.0022 ;$ Fig. $2 b$ ) but no difference in testis weight was seen between the $\beta E R K O$ mice and their wild-type controls ( $t$-test; $P=0.24$ ).

Histological sections from wild-type littermates of both the $\alpha$ ERKO and the $\beta E R K O$ exhibited normal testicular histology with full spermatogenesis (Fig. 3). The testes of the $\alpha$ ERKO male mice showed disrupted seminiferous tubules with a partial or complete loss of germ cells. In the most severely affected tubules, Sertoli cells were seen lining the otherwise empty tubules. The testes from the $\beta E R K O$ mice appeared to show a normal histology with complete spermatogenesis. However, within the interstitial tissue there appeared to be increased numbers of Leydig cells.

\section{Stereology}

When the volume contributed by seminiferous tubules and interstitial tissue was estimated using tissue point counting, no significant differences were seen between the $\alpha E R K O$ and the $\beta E R K O$ mice and their respective wild-type littermates in the percentage of seminiferous tubules (92.9-93.9\%) and the interstitial tissue $(6.1-7.1 \%)$, despite the severe cellular loss in some but not all $\alpha$ ERKO tubules.
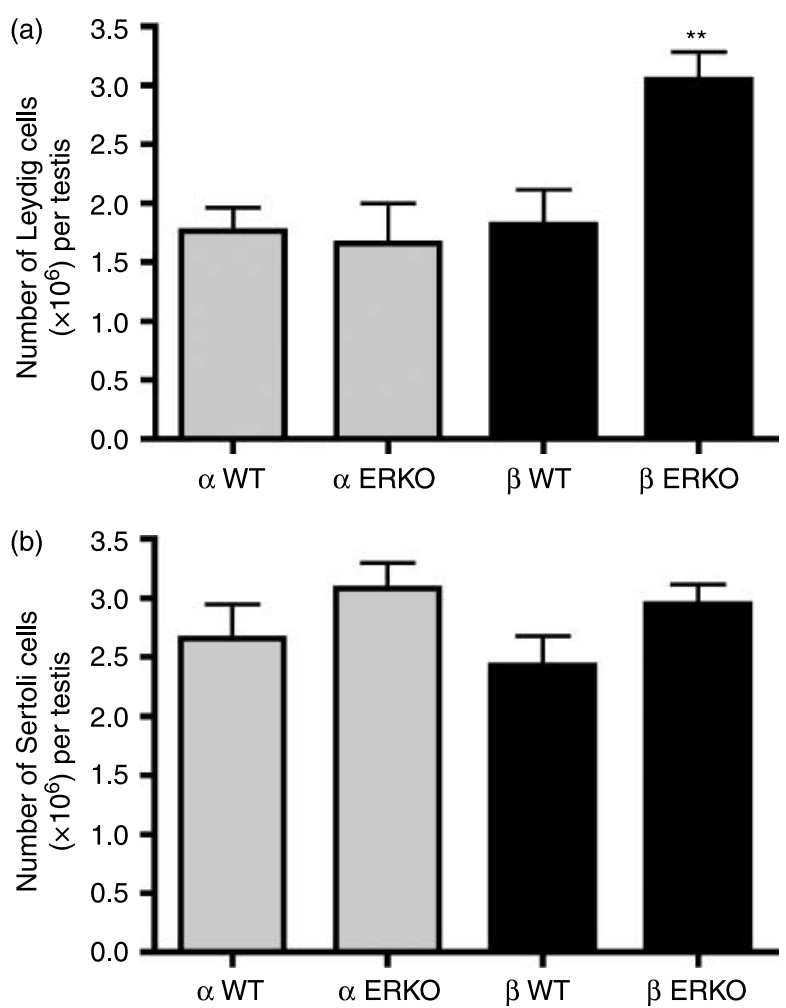

Figure 4 The total number of (a) Leydig cells and (b) Sertoli cells per testis in $\alpha$ and $\beta$ oestrogen receptor knockout mice. Bars represent mean \pm s.E.M. $\alpha \mathrm{WT} n=8, \alpha$ ERKO $n=8, \beta \mathrm{WT} n=5, \beta$ ERKO $n=8$. ${ }^{* *} P<0.01$ when compared with $\beta$ wild-type mice.
The fractionator method and optical disector were used to evaluate the effect of loss of ER $\alpha$ and $E R \beta$ on the individual cell types within the testis. The number of Leydig cells per testis was significantly increased ( $t$-test; $P=0.0078)$ in $\beta E R K O$ mice when compared with their wild-type littermates (Fig. 4a) with $\sim 40 \%$ more Leydig cells observed in the $\beta E R K O$ mice. No significant difference was observed in the number of Leydig cells per testis in the $\alpha$ ERKO when compared with their respective wild-types ( $t$-test; $P=0.79$ ). There were no differences seen in Sertoli cell numbers per testis in the $\beta$ ERKO ( $t$-test; $P=0.099$ ) or the $\alpha$ ERKO mice ( $t$-test; $P=0.27)$ when compared with their wild-type littermates (Fig. 4b).
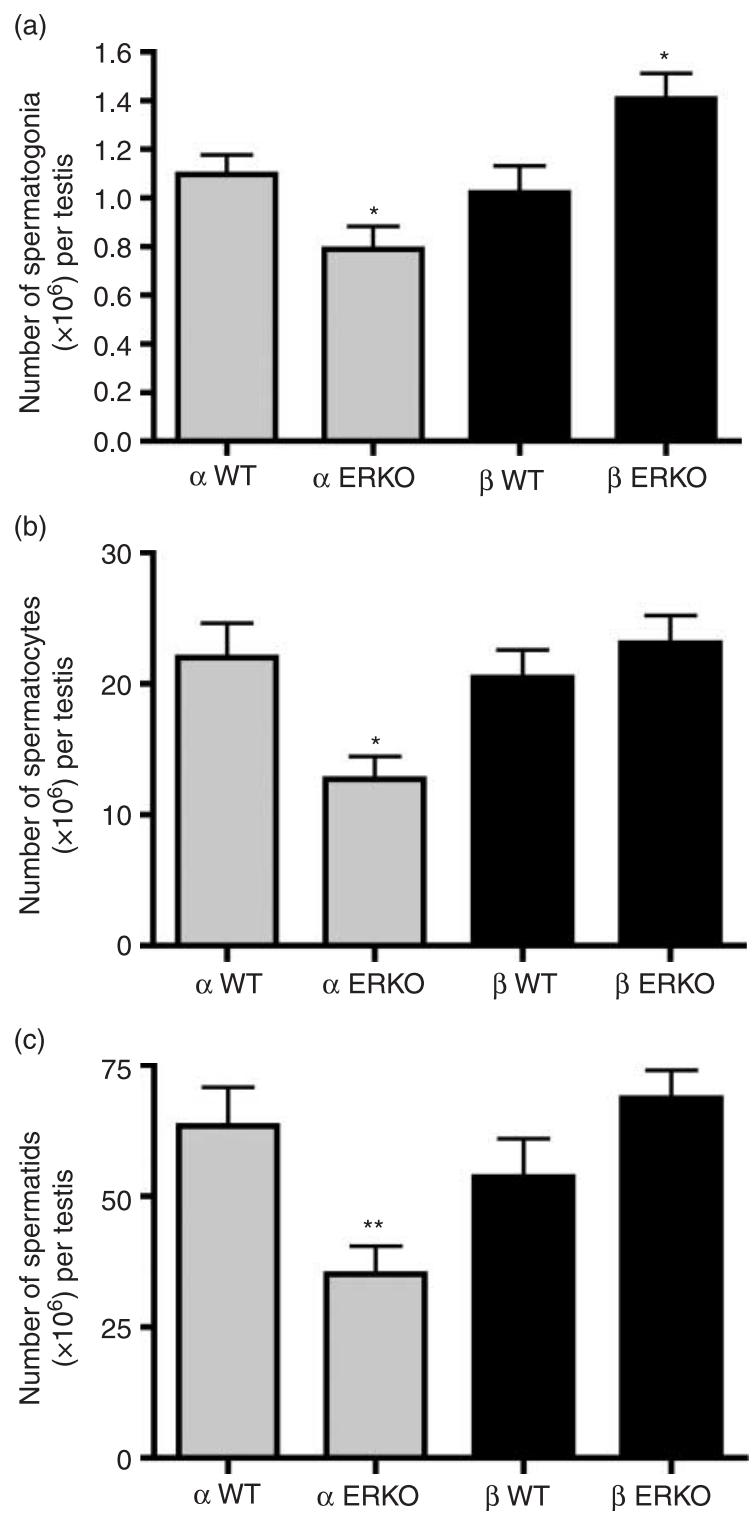

Figure 5 The total number of (a) spermatogonia, (b) spermatocytes and (c) spermatids per testis from $\alpha$ and $\beta$ oestrogen receptor knockout mice. Bars represent mean \pm S.E.M. $\alpha \mathrm{WT} n=8, \alpha$ ERKO $n=8, \beta \mathrm{WT} n=5, \beta$ ERKO $n=8 . * P<0.05,{ }^{*} * P<0.01$ when compared with $\beta$ wild-type mice. 
(a)

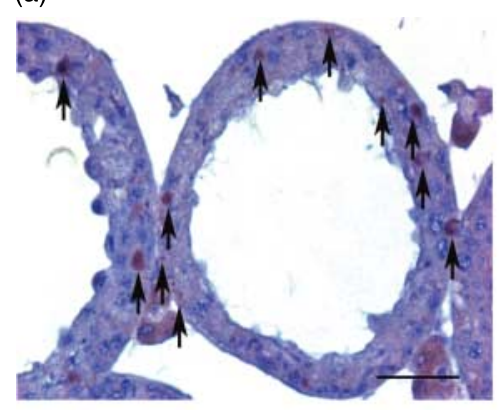

(d)

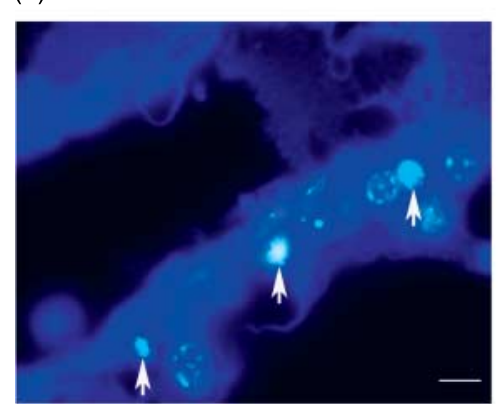

(b)

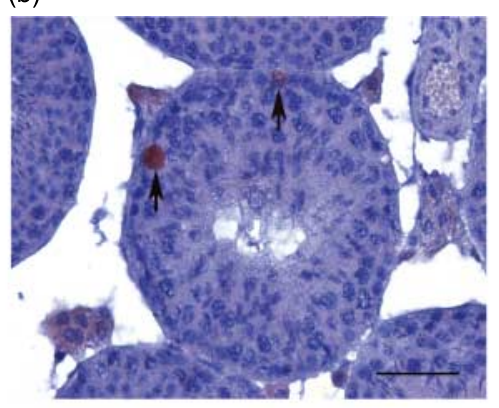

(e)

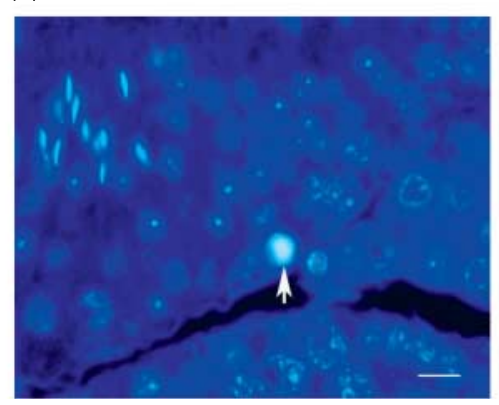

(c)

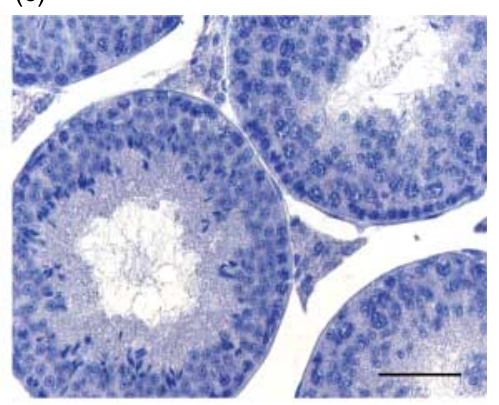

(f)

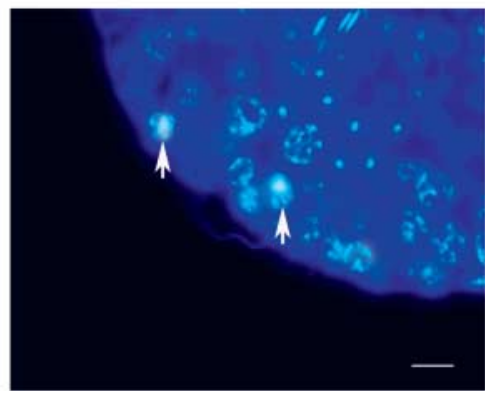

Figure 6 Immunohistochemistry for active caspase-3 (a-c). (a) Active caspase-3 apoptotic cells seen in the testis sections from $\alpha$ ERKO mice. Testis sections from the $\beta E R K O$ mice (b) and both the $\alpha$ ERKO and $\beta E R K O$ wild-type littermates (not shown) had only occasional active caspase- 3 immunoreactive cells. Arrows indicate immunopositive cells. The rabbit lgG control (c) showed no immunopositive staining. Bars $=50 \mu \mathrm{m}$. Hoechst stained testis sections $(d-f)$ allowed identification of apoptotic cells using morphological criteria as indicated by arrows. (d) There was a significant increase in cell numbers in the testis sections from $\alpha$ ERKO mice. Both the $\beta E R K O$ mice (e) and the wild-type littermates (f) showed only the occasional apoptotic cell. Bars $=10 \mu \mathrm{m}$.

A significant loss of all germ cells per testis was seen in the $\alpha$ ERKO mice; spermatogonia ( $t$-test; $P=0.024)$, spermatocytes ( $t$-test; $P=0.0106$ ) and spermatids ( $t$-test; $P=0.008$; Fig. 5) compared to their wild-type littermates. Conversely, spermatogonial numbers per testis were significantly increased in the $\beta E R K O$ mice ( $t$-test; $P=0.033$ ). No significant change in the number of spermatocytes per testis ( $t$-test; $P=0.43$ ) or spermatids per testis ( $t$-test; $P=0.12$ ) was observed in the $\beta E R K O$ mice when compared with the $\beta$ wild-type animals.

In all groups, active caspase- 3 was immunolocalised only to the spermatocytes of the testes (Fig. $6 a-c$ ). There were no significant differences in the number of cells per testis showing immunoreactivity for active caspase-3 cells ( $t$-test; $P=0.63$ ) between the $\beta E R K O$ and wild-type mice. The numbers of active caspase-3 immunopositive cells per testis in the $\alpha$ ERKO were, however, increased significantly ( $t$-test; $P=0.0008$ ) when compared with their wild-type littermates (Fig. 7a).

Hoechst staining was used to strengthen the results seen in the active caspase-3, as this stain identifies apoptotic cells by nuclear morphology. Predominantly, spermatocytes were seen as Hoechst-positive but one or two round spermatids per section were also seen. Both cell types were included in the total number of apoptotic cells (Fig. $6 d-f$ ). Once more, there were no significant differences in the number of cells per testis, showing reactivity for Hoechst between the $\beta$ ERKO and wild-type mice ( $t$-test, $P=0.95$ ). The numbers of Hoechst-positive cells per testis in the $\alpha \mathrm{ERKO}$ were significantly increased ( $t$-test; $P=0.046)$ when compared with their wild-type littermates (Fig. $7 b$ ).

\section{Testosterone concentrations}

Plasma and testicular testosterone concentrations (Fig. 8) were significantly increased ( $t$-test; $P<0.0001$ plasma; $P=0.0013$ testes) in the $\alpha$ ERKO mice when compared with their wild-type littermates. Despite the increased number of Leydig cells per testis in the $\beta E R K O$ mice there was no significant increase in testicular testosterone ( $t$-test; $P=0.81$ ) or plasma testosterone ( $t$-test; $P=0.51)$ concentrations in these animals, when compared with the wild-type mice.

\section{Mean Leydig cell volume}

Leydig cell volumes were significantly increased in the $\alpha$ ERKO mice ( $t$-test, $P=0.0003$ ). Moreover, Leydig cell volumes were significantly decreased in the $\beta E R K O$ mice ( $t$-test, $P=0.0171$; Fig. 9) when compared with their wild-type littermates. 
(a)

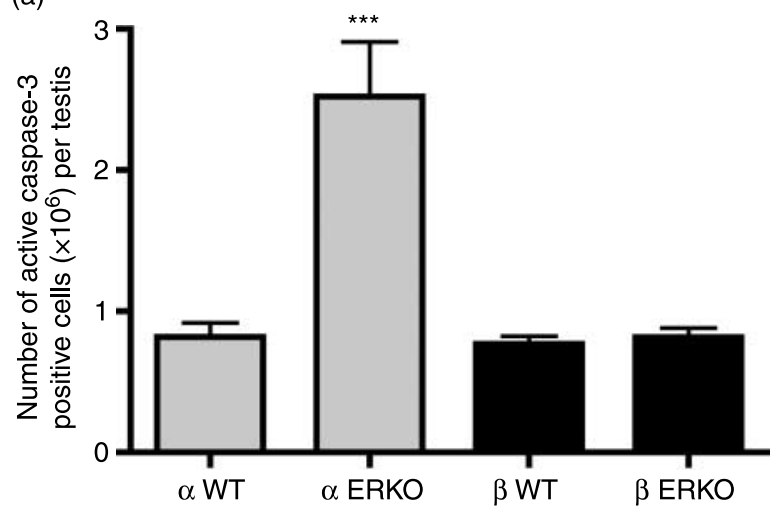

(b)

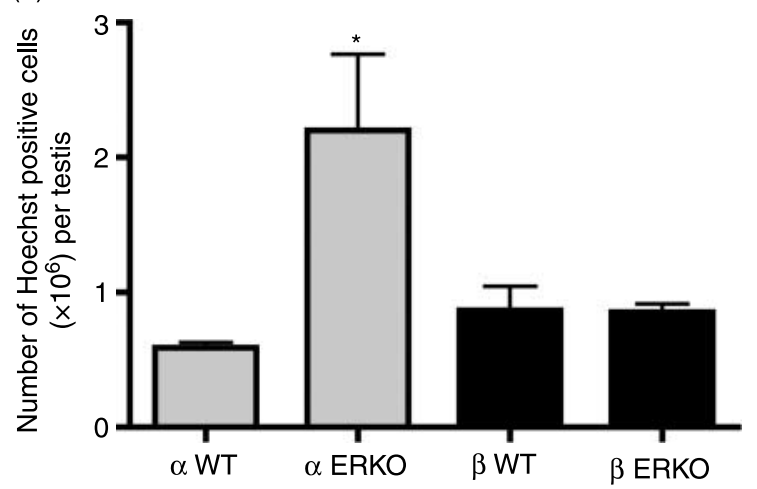

Figure 7 (a) The total number of apoptotic spermatocytes indicated by active caspase- 3 immunostained cells per mouse testis between the $\alpha$ and the $\beta$ oestrogen receptor knockout mice. Bars represent mean \pm S.E.M. $\alpha$ WT $n=8, \alpha$ ERKO $n=8, \beta \mathrm{WT} n=5, \beta$ ERKO $n=8$.

${ }^{* * *} P<0.001$ when compared with $\alpha$ wild-type mice. (b) The total number of apoptotic cells as indicated by Hoechst staining per testis of the $\alpha$ and $\beta$ ERKO mice and their respective wild-types. Bars represent mean \pm S.E.M. $\alpha \mathrm{WT} n=3, \alpha$ ERKO $n=3, \beta \mathrm{WT} n=3, \beta \mathrm{ERKO}$ $n=3$. ${ }^{*} P<0.05$ when compared with $\alpha$ wild-type mice.

\section{Discussion}

This study confirms earlier reports that there is a major disruption of spermatogenesis in the adult $\alpha$ ERKO mice (Lubahn et al. 1993) and that apparently testicular morphology is unaltered following loss of the ER $\beta$ (Krege et al. 1998). However, our data show that inactivation of the $E R \beta$ gene does affect the cellular composition of the testis (Table 1) and demonstrates that confining a study to qualitative assessment and sperm output may not provide an accurate picture of testicular morphology.

The results show that the number of adult Leydig cells per testis was unaffected by the inactivation of the ER $\alpha$, however, loss of ER $\beta$ resulted in a $40 \%$ increase. This is in contrast with fetal Leydig cells where it has been shown that loss of neither ER $\alpha$ nor $\beta$ affects the number of cells in the mouse 2 days post partum (Delbes et al. 2004, 2005). Fetal Leydig cells express ER $\alpha$ but have not, as yet, been shown to express ER $\beta$ (Jefferson et al. 2000), which may explain the lack of effect of ER $\beta$ on these
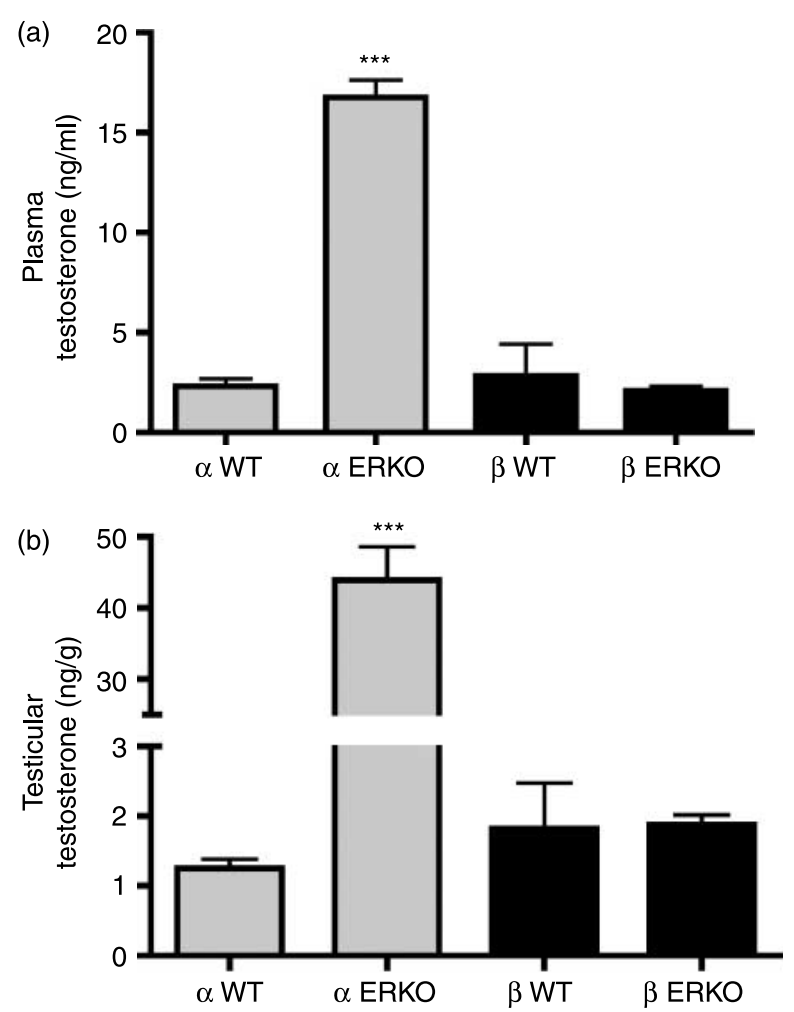

Figure 8 Testosterone concentrations in (a) plasma (b) testis in the $\alpha$ and the $\beta$ oestrogen receptor knockout mice. Bars represent mean \pm S.E.M. $\alpha \mathrm{WT} n=8, \alpha$ ERKO $n=8, \beta \mathrm{WT} n=5, \beta$ ERKO $n=8 .{ }^{* * *} p<0.0001$ when compared with wild-type mice.

cells. Our data suggest that activation of ER $\beta$ may normally have an inhibitory effect on the regulation of adult Leydig cell number.

As well as affecting Leydig cell number, oestrogen also affects the steroidogenic capacity of the Leydig cell. Studies using aromatase-deficient mice have shown that these animals have elevated circulating testosterone and LH and hyperplastic Leydig cells (Robertson et al. 1999). Our data confirm earlier studies that the inhibitory effect of oestrogen on testosterone production may be

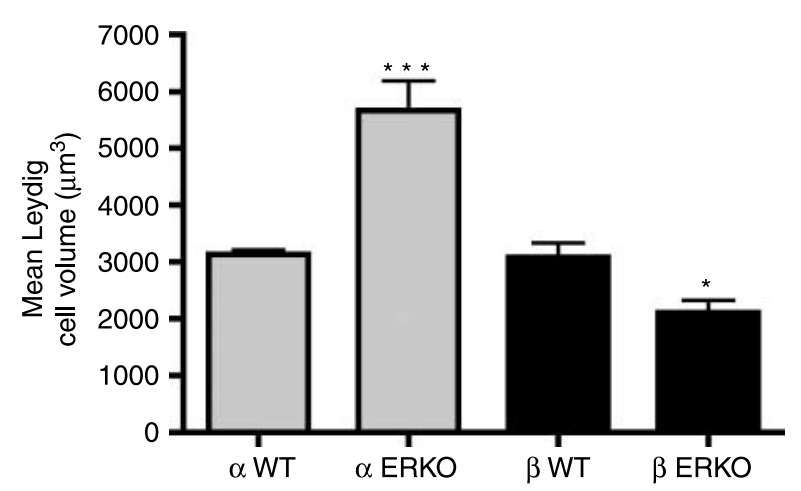

Figure 9 Mean Leydig cell volume in $\alpha$ and $\beta E R K O$ mice and their respective wild-types. Bars represent mean \pm S.E.M. $\alpha \mathrm{WT} n=8, \alpha$ ERKO $n=8, \beta$ WT $n=5, \beta$ ERKO $n=8 .{ }^{* * *} P<0.001,{ }^{*} P<0.05$ when compared with wild-type mice. 
Table 1 Summary of the effects of loss on the testis of oestrogen receptor $\alpha(E R \alpha)$ and $\beta(E R \beta)$ when compared with wild-type mice.

\begin{tabular}{lcl}
\hline Parameter & $\alpha$ ERKO & BERKO \\
\hline Testis weight & $\downarrow$ & $=$ \\
Leydig cell number per testis & $=$ & $\uparrow 68 \%$ \\
Leydig cell volume & $\uparrow$ & $=$ \\
Plasma testosterone & $\uparrow$ & $=$ \\
Number of Sertoli cells per testis & $=$ & $\uparrow 38 \%$ \\
Number of spermatogonia per testis & $\downarrow 28 \%$ & $=$ \\
Number of spermatocytes per testis & $\downarrow 42 \%$ & $=$ \\
Number of spermatids per testis & $\downarrow 45 \%$ & $=$ \\
Germ cell apoptosis per testis & $\uparrow$ & \\
\hline
\end{tabular}

mediated by ER $\alpha$ since $\alpha$ ERKO mice display similar changes to mice deficient of oestrogen (Oliveira et al. 2002). On the other hand, $\beta E R K O$ mice, despite having increased Leydig cells per testis, have normal plasma and testicular testosterone concentrations and circulating $\mathrm{LH}$ levels (Temple et al. 2003). At the cellular level these Leydig cells had a smaller volume suggesting a decrease in testosterone production by each individual cell. Since these changes occur in the presence of normal LH levels this suggests that activation of $E R \beta$, unlike $E R \alpha$, may normally mediate a direct stimulatory effect on testosterone production in the adult Leydig cell. Such an effect is not observed in fetal Leydig cells which lack ER $\beta$ (Delbes et al. 2004).

In the rat, there is evidence that administration of exogenous oestrogens and/or xenoestrogens during development may inhibit Sertoli cell number in the adult (Atanassova et al. 1999). The evidence for a role of oestrogen in Sertoli cell proliferation in the mouse is less clear. Sertoli cell numbers were unchanged in the aromatase-deficient mouse (Robertson et al. 1999). Similarly, no effect on Sertoli cell number per testis was seen in either the $\alpha$ ERKO or the $\beta E R K O$ mice in the present study when compared with their respective wild-type littermates. This is perhaps surprising since $E R \propto m R N A$ and protein are expressed in Sertoli cells and, while ER $\beta$ mRNA expression has yet to be demonstrated, the protein has been reported in these cells (Zhou et al. 2002). The reported effects of exogenous oestrogens on Sertoli cell number in the rat (Atannasova et al. 1999) may thus be a species specific effect or reflect the fact that Sertoli cell proliferation is only inhibited by supraphysiological levels of oestrogen. The latter is supported by Robertson et al. (2002) who demonstrated that a soy containing diet may decrease Sertoli cell number in the wild-type but not the aromatase knockout mouse.

The effects of the loss of the ER $\alpha$ receptor on germ cells have been previously described (Lubahn et al. 1993). Gonocyte number was found to be normal in the neonatal aERKO mice (Delbes et al. 2005) but spermatogenesis progressively became disrupted due to the increased tubular pressure relating to reduced fluid reabsorption in the efferent ducts (Hess 2000). Our findings of increased caspase-3-positive staining and fragmented pyknotic nuclei using the Hoechst stain confirm that perturbations of the efferent ducts increase the rate of apoptosis in germ cells.

The effects of inactivation of ER $\beta$ in the adult mouse have not previously been described. Delbes et al. (2004) have demonstrated that an increased number of gonocytes are present in the 2-day-old $\beta E R K O$ mice and suggested that this increase results from an increase in cell proliferation and decreased apoptosis. A similar increase in the number of spermatocytes per testis was observed in 11-week-old mice in this study. There were, however, no significant increases in the number of meiotic germ cells in these mice. The lack of an increased rate of germ cell apoptosis and the presence of normal circulating FSH concentrations in the $\beta E R K O$ mice (Temple et al. 2003) suggests that while there may be a larger pool of spermatogonia persisting in the adult mouse the number being recruited into spermatogenesis at any one time is not affected by the presence or absence of ER $\beta$. Further studies are required to test this hypothesis.

\section{Conclusion}

In conclusion, this study demonstrates that in the mouse ER $\beta$ is involved in the regulation of adult Leydig cell number and may also affect the steroidogenic capacity of individual Leydig cells. In addition, the disrupted endocrine profile in the $\alpha \mathrm{ERKO}$ mouse resulted in hypertrophic Leydig cells and profound cellular loss through active caspase-3 activation in the spermatocytes.

\section{Acknowledgments}

The authors declare that there is no conflict of interest that would prejudice the impartiality of this scientific work.

\section{References}

Akingbemi BT, Ge R, Rosenfeld CS, Newton LG, Hardy DO, Catterall JF, Lubahn DB, Korach KS \& Hardy MP 2003 Estrogen receptor- $\alpha$ gene deficiency enhances androgen biosynthesis in the mouse Leydig cell. Endocrinology 144 84-93.

Atanassova N, McKinnell C, Walker M, Turner KJ, Fisher JS, Morley M, Millar MR, Groome NP \& Sharpe RM 1999 Permanent effects of neonatal estrogen exposure in rats on reproductive hormone levels, Sertoli cell number, and the efficiency of spermatogenesis in adulthood. Endocrinology 140 5364-5373.

Clermont Y \& Perey B 1957 The stages of the cycle of the seminiferous epithelium of the rat: practical definitions in PA-Schiff-hematoxylin and hematoxylin-eosin stained sections. Revue Canadienne de Biologie 16 451-462.

Couse JF \& Korach KS 1999 Estrogen receptor null mice: what have we learned and where will they lead us? Endocrine Reviews 20 358-417.

Couse JF, Yates MM, Walker VR \& Korach KS 2003 Characterization of the hypothalamic-pituitary-gonadal axis in estrogen receptor (ER) 
null mice reveals hypergonadism and endocrine sex reversal in females lacking ER $\alpha$ but not ER $\beta$. Molecular Endocrinology 17 1039-1053.

Delbes G, Levacher C, Pairault C, Racine C, Duquenne C, Krust A \& Habert R 2004 Estrogen receptor $\beta$-mediated inhibition of male germ cell line development in mice by endogenous estrogens during perinatal life. Endocrinology 145 3395-3403.

Delbes G, Levacher C, Duquenne C, Racine C, Pakarinen P \& Habert R 2005 Endogenous estrogens inhibit mouse fetal Leydig cell development via estrogen receptor $\alpha$. Endocrinology 146 2454-2461.

Fenwick MA \& Hurst PR 2002 Immunohistochemical localization of active caspase- 3 in the mouse ovary: growth and atresia of small follicles. Reproduction 124 659-665.

Fink JW, McLeod BJ, Assinder SJ, Parry LJ \& Nicholson HD 2005 Seasonal changes in mesotocin and localization of its receptor in the prostate of the brushtail possum (Trichosurus vulpecula). Biology of Reproduction 72 470-478.

Gundersen HJ 1986 Stereology of arbitrary particles. A review of unbiased number and size estimators and the presentation of some new ones, in memory of William $\mathrm{R}$ Thompson. Journal of Microscopy 143 3-45.

Gundersen HJ 2002 The smooth fractionator. Journal of Microscopy 207 191-210.

Gundersen HJ \& Jensen EB 1987 The efficiency of systematic sampling in stereology and its prediction. Journal of Microscopy 147 229-263.

Gundersen HJ, Bagger P, Bendtsen TF, Evans SM, Korbo L, Marcussen N, Moller A, Nielsen K, Nyengaard JR, Pakkenberg B et al. 1988 The new stereological tools: disector, fractionator, nucleator and point sampled intercepts and their use in pathological research and diagnosis. APMIS 96 857-881.

Hess RA 2000 Oestrogen in fluid transport in efferent ducts of the male reproductive tract. Reviews of Reproduction 5 84-92.

Howard CV \& Reed MG 1998 Unbiased Stereology - Three Dimensional Measurement in Microscopy, Oxford: Bioscientific Publishers.

Jefferson WN, Couse JF, Banks EP, Korach KS \& Newbold RR 2000 Expression of estrogen receptor $\beta$ is developmentally regulated in reproductive tissues of male and female mice. Biology of Reproduction 62 310-317.

Krege JH, Hodgin JB, Couse JF, Enmark E, Warner M, Mahler JF, Sar M, Korach KS, Gustafsson JA \& Smithies O 1998 Generation and reproductive phenotypes of mice lacking estrogen receptor $\beta$. PNAS 95 15677-15682.

Leblond CP \& Clermont Y 1952 Spermatogenesis of rat, mouse, hamster and guinea pig as revealed by the 'periodic acid-fuchsin sulfurous acid' technique. American Journal of Anatomy 90 $167-215$.

Lindzey J, Wetsel WC, Couse JF, Stoker T, Cooper R \& Korach KS 1998 Effects of castration and chronic steroid treatments on hypothalamic gonadotropin-releasing hormone content and pituitary gonadotropins in male wild-type and estrogen receptor- $\alpha$ knockout mice. Endocrinology 139 4092-4101.

Lubahn DB, Moyer JS, Golding TS, Couse JF, Korach KS \& Smithies O 1993 Alteration of reproductive function but not prenatal sexual development after insertional disruption of the mouse estrogen receptor gene. PNAS 90 11162-11166.

Nitta H, Bunick D, Hess RA, Janulis L, Newton SC, Millette CF, Osawa Y, Shizuta Y, Toda K \& Bahr JM 1993 Germ cells of the mouse testis express P450 aromatase. Endocrinology 132 1396-1401.
O'Donnell L, Robertson KM, Jones ME \& Simpson ER 2001 Estrogen and spermatogenesis. Endocrine Reviews 22 289-318.

Oliveira CA, Zhou Q, Carnes K, Nie R, Kuehl DE, Jackson GL, Franca LR, Nakai M \& Hess RA 2002 ER function in the adult male rat: short- and long-term effects of the antiestrogen ICI 182,780 on the testis and efferent ductules, without changes in testosterone. Endocrinology 143 2399-2409.

Pentikainen V, Erkkila K, Suomalainen L, Parvinen M \& Dunkel L 2000 Estradiol acts as a germ cell survival factor in the human testis in vitro. Journal of Clinical Endocrinology and Metabolism 85 2057-2067.

Pierantoni R, Iela L, d'Istria M, Fasano S, Rastogi RK \& Delrio G 1984 Seasonal testosterone profile and testicular responsiveness to pituitary factors and gonadotrophin releasing hormone during two different phases of the sexual cycle of the frog (Rana esculenta). Journal of Endocrinology 102 387-392.

Robertson KM, O'Donnell L, Jones ME, Meachem SJ, Boon WC, Fisher CR, Graves KH, McLachlan RI \& Simpson ER 1999 Impairment of spermatogenesis in mice lacking a functional aromatase (cyp 19) gene. PNAS 96 7986-7991.

Robertson KM, O'Donnell L, Simpson ER \& Jones ME 2002 The phenotype of the aromatase knockout mouse reveals dietary phytoestrogens impact significantly on testis function. Endocrinology 143 2913-2921.

Rosenfeld CS, Ganjam VK, Taylor JA, Yuan X, Stiehr JR, Hardy MP \& Lubahn DB 1998 Transcription and translation of estrogen receptor- $\beta$ in the male reproductive tract of estrogen receptor- $\alpha$ knock-out and wild-type mice. Endocrinology 139 2982-2987.

Russell L, Ettlin RA, Sinha Hikim AP \& Clegg ED 1990 Histological and histopathological evaluation of the testis, Vienna: Cache River Press.

Shi SR, Cote RJ, Young L, Imam SA \& Taylor CR 1996 Use of pH 9.5 Tris- $\mathrm{HCl}$ buffer containing 5\% urea for antigen retrieval immunohistochemistry. Biotechnic and Histochemistry 71 190-196.

Sterio DC 1984 The unbiased estimation of number and sizes of arbitrary particles using the disector. Journal of Microscopy 134 127-136.

Temple JL, Scordalakes EM, Bodo C, Gustafsson JA \& Rissman EF 2003 Lack of functional estrogen receptor $\beta$ gene disrupts pubertal male sexual behavior. Hormones and Behavior 44 427-434.

Wreford NG 1995 Theory and practice of stereological techniques applied to the estimation of cell number and nuclear volume in the testis. Microscopy Research and Technique 32 423-436.

Yeung WS, Guldenaar SE, Worley RT, Humphrys J \& Pickering BT 1988 Oxytocin in Leydig cells: an immunocytochemical study of Percoll purified cells from rat testes. Cell and Tissue Research 253 463-468.

Zhai J, Lanclos KD \& Abney TO 1996 Estrogen receptor messenger ribonucleic acid changes during Leydig cell development. Biology of Reproduction 55 782-788.

Zhou Q, Nie R, Prins GS, Saunders PT, Katzenellenbogen BS \& Hess RA 2002 Localization of androgen and estrogen receptors in adult male mouse reproductive tract. Journal of Andrology 23 870-881.

Received 16 January 2007

First decision 14 February 2007

Revised manuscript received 18 March 2007

Accepted 17 May 2007 